\title{
Deletion of Alzheimer's Disease Risk Gene ABCA7 Alters White Adipose Tissue Development and Leptin Levels
}

\author{
Surabhi Bhatia ${ }^{\mathrm{a}, 1}$, YuHong Fu ${ }^{\mathrm{a}, 1}$, Jen-Hsiang T. Hsiao ${ }^{\mathrm{a}, \mathrm{b}}$, Glenda M. Halliday ${ }^{\mathrm{a}, \mathrm{b}}$ \\ and Woojin Scott Kim ${ }^{\mathrm{a}, \mathrm{b}, *}$ \\ ${ }^{a}$ Brain and Mind Centre, Sydney Medical School, The University of Sydney, Camperdown, NSW, Australia \\ ${ }^{\mathrm{b}}$ School of Medical Sciences, University of New South Wales and Neuroscience Research Australia, \\ Randwick, NSW, Australia
}

Accepted 17 November 2017

\begin{abstract}
ATP-binding cassette A7 (ABCA7) is a genetic risk factor for late-onset Alzheimer's disease (AD). It belongs to a group of transporter genes that specializes in regulating lipid transport in the periphery as well as in the brain. ABCA7 has been implicated in a number of roles relating to $\mathrm{AD}$ pathology, including phagocytic clearance of amyloid- $\beta$ peptides. We have discovered that deletion of ABCA7 in mouse causes a dramatic reduction in white adipose tissue (WAT) in female mice. WAT is important in $\mathrm{AD}$ context because it is the primary producer of leptin, which is a hormone that is known to modulate AD neuropathology. WAT in male Abca $7^{-1-}$ mice was not altered. The pathological link between ABCA7 and WAT that impacts on $\mathrm{AD}$ is unknown. Our transcription analysis revealed that lipin-1 expression was significantly upregulated in female $\mathrm{Abca} 7^{-/}$mice, indicating that ABCA7 affects WAT development. The circulating leptin level was significantly reduced in female $\mathrm{Abca} 7^{-/}$mice without any change in WAT leptin mRNA or protein expression, indicating that ABCA7 does not affect leptin production, but alters the circulating leptin level indirectly by affecting WAT development. Insulin is a key hormone that regulates WAT development, i.e., adipogenesis, and it was significantly reduced in female $\mathrm{Abca} 7^{-1}$ mice. These data when put together suggest that ABCA7 plays a role in regulating WAT development and consequently circulating leptin levels, which are known to modulate $\mathrm{AD}$ neuropathology.
\end{abstract}

Keywords: ABCA7, adipogenesis, Alzheimer's disease, insulin, leptin, white adipose tissue

\section{INTRODUCTION}

ABCA7 is a member of the ATP-binding cassette subfamily A (ABCA) that specializes in regulating lipid transport and maintaining lipid homeostasis [1-3]. Recent large genome-wide association and sequencing studies have revealed that ABCA7 is a strong risk factor for late-onset Alzheimer's disease (AD) [4-7]; ABCA7 is one of top 10

\footnotetext{
${ }^{1}$ These authors contributed equally to this work.

*Correspondence to: Associate Professor W. S. Kim, Brain and Mind Centre, Sydney Medical School, The University of Sydney, Camperdown, NSW 2050, Australia. Tel.: +61 29351 0705; E-mail: woojin.kim@sydney.edu.au.
}

AD susceptibility genes [4, 8]. ABCA7 was first described to play a role in regulating cellular cholesterol and phospholipid transport [2,3]. Since then, a number of roles relating to $\mathrm{AD}$ pathology have been described, including a role in phagocytic clearance of amyloid- $\beta$ (A $\beta$ ) peptides [9-12] and in regulating amyloid- $\beta$ protein precursor $(\mathrm{A} \beta \mathrm{PP})$ processing to generate $A \beta$ peptides [13-15]. Thus far, evidence suggests that ABCA7 affects multiple pathways impacting AD pathology.

The first study of Abca7 knockout mice revealed that deletion of ABCA7 caused a dramatic reduction in the size of white adipose tissue (WAT) [16]. WAT is important in the $\mathrm{AD}$ context because it is the primary 
producer of leptin, which is known to modulate the levels of AD neuropathology [17-19]. The level of leptin in circulation is dependent on WAT size, i.e., the larger the WAT the higher the leptin level [20,21]. Leptin is a metabolic hormone that was originally discovered to suppress appetite and regulate energy expenditure [22]. Since its discovery in 1994, leptin has been shown to have other important physiological roles. A substantial body of evidence indicates that leptin regulates a number of features defining $\mathrm{AD}$ at the molecular and physiological levels, and that a deficiency in leptin levels may contribute to central nervous system abnormalities leading to AD. Studies have shown that AD patients have significantly decreased circulating leptin levels [23]. A large prospective study of 2,871 subjects demonstrated that elderly individuals, followed over 4 years, with high leptin levels were less likely to develop AD than those with low leptin levels [24]. Another study followed 785 healthy individuals from the Framingham cohort for 8.3 years and showed that higher leptin levels were associated with a lower risk of $\mathrm{AD}$ [25]. Therefore, the circulating leptin level is inversely correlated with $\mathrm{AD}$ risk, i.e., the higher the leptin level the lower the AD risk.

The pathological link between ABCA7 and WAT that impacts on $\mathrm{AD}$ is unknown. We therefore proposed a hypothesis that ABCA7 regulates WAT development and leptin levels and consequently modifies $\mathrm{AD}$ neuropathology. In this study we investigate the link between ABCA7 and WAT development, and determine how ABCA7 alters leptin levels.

\section{MATERIALS AND METHODS}

\section{Animals}

ABCA7 knockout (Abca7 ${ }^{-/}$) mice were from Prof Mason Freeman (Massachusetts General Hospital, Boston). They were established on the C57BL/6J background and backcrossed $>20$ generations. Abca7 $7^{-/}$mice are homozygous for the transgene and the genotype was confirmed by Southern hybridization and polymerase chain reaction (PCR) [16]. Age-matched ( $\sim 5$ months) wild type C57BL/6J mice were used as non-transgenic controls. Mice were kept in polysulfone cages (2-4 mice/cage) under a $12: 12 \mathrm{~h}$ light:dark schedule with food and water available ad libitum. Each cage provided the same environment and featured a polycarbonate igloo and nesting material. Animal experimental procedures were in accordance with the Australian Code for the Care and Use of Animals in Research and were approved by the Animal Care and Ethics Committee of the University of New South Wales.

\section{Tissue processing}

Mice were injected (i.p.) with a lethal dose of pentobarbitone sodium. Blood $(\sim 0.5 \mathrm{ml})$ was collected from the right heart ventricle and plasma prepared. Transcardial perfusion was performed with phosphate buffered saline (PBS; pH 7.4) through the left heart ventricle. Perigonadal white adipose tissue (WAT) deposits were collected. The left deposit was snap-frozen for subsequent RNA and protein analyses. The right deposit was drop-fixed in the $4 \%$ paraformaldehyde (in 0.1 M PBS, pH 7.4) at $4^{\circ} \mathrm{C}$ for 4 days for histological analysis.

\section{Histology}

The fixed WAT was embedded in paraffin as described previously [26]. The $5 \mu \mathrm{m}$ sections were prepared and stained with hematoxylin and eosin (H\&E). The five representative photos of each section were taken at 20x magnification with an Axioskop microscope (Zeiss Germany) using AxioCAM Mrc camera. The images were stored in uncompressed 24-bit color TIFF format and analyzed using Image $\mathrm{J}$ based Adiposoft software as described previously [27].

\section{RNA extraction and quantitative PCR}

RNA was isolated using TRIzol reagent (Invitrogen) following the manufacturer's protocol. All procedures were carried out using RNase-free reagents and consumables. One microgram of RNA was reverse transcribed into cDNA using Moloney-murine leukemia virus (M-MLV) reverse transcriptase and random primers (Promega, Madison, Wisconsin, USA) in $20 \mu \mathrm{l}$ reaction volume. Quantitative PCR (qPCR) assays were carried out using a Mastercycler ep realplex S (Eppendorf, Sydney, Australia) and the fluorescent dye SYBR Green (Bio-Rad), following the manufacturer's protocol. Briefly, each reaction $(20 \mu \mathrm{l})$ contained $1 \mathrm{x}$ mastermix, 5 pmoles of primers and $1 \mu$ l of cDNA template. Amplification was carried out with 40 cycles of $94^{\circ} \mathrm{C}$ for $15 \mathrm{~s}$ and $60^{\circ} \mathrm{C}$ for $1 \mathrm{~min}$. Gene 
expression was normalized to the housekeeper gene GAPDH. A no-template control was included for each PCR amplification assay. The level of expression for each gene was calculated using the comparative threshold cycle $(\mathrm{Ct})$ value method using the formula $2^{-\Delta \Delta \mathrm{Ct}}$ (where $\Delta \Delta \mathrm{Ct}=\Delta \mathrm{Ct}$ sample $-\Delta \mathrm{Ct}$ reference).

\section{ELISA}

Plasma leptin and insulin were measured by ELISA following manufacturer's protocols - leptin (Millipore cat.\# EZML-82K) and insulin (Millipore cat.\# EZRMI-13K). WAT leptin was also measured by ELISA. Protein lysates were prepared from WAT by homogenization of $100 \mathrm{mg}$ of tissue in chilled sucrose buffer $(250 \mathrm{mM}$ sucrose, $10 \mathrm{mM}$ HEPES pH 7.4, $1 \mathrm{mM}$ EDTA) supplemented with protease inhibitor cocktail (Roche), followed by centrifugation at $1000 \mathrm{~g}$ for $10 \mathrm{~min}$ at $4^{\circ} \mathrm{C}$.

\section{Cell culturing and adipocyte differentiation}

3T3-L1 preadipocytes were cultured in Dulbecco's modified Eagle's medium (DMEM) containing 10\% fetal bovine serum (FBS), $100 \mathrm{IU} / \mathrm{ml}$ penicillin and $100 \mu \mathrm{g} / \mathrm{ml}$ streptomycin at $37^{\circ} \mathrm{C}$ in humidified air containing $5 \% \mathrm{CO}_{2}$. The $3 \mathrm{~T} 3-\mathrm{L} 1$ cells were differentiated into adipocytes as described previously [28]. Briefly, they were grown to $90 \%$ confluence and treated with $0.5 \mathrm{mM}$ methyl-isobutylxanthine (Sigma I17018), $1 \mu \mathrm{M}$ dexamethasone (Sigma D4902) and $5 \mu \mathrm{g} / \mathrm{ml}$ insulin (Sigma I0516). After 2 days the media was replaced with DMEM supplemented with $10 \% \mathrm{FBS}$ and $5 \mu \mathrm{g} / \mathrm{ml}$ insulin. Thereafter, the media was replaced every two days for $\sim 10$ days. Differentiated adipocytes were confirmed by Oil O Red staining of the lipid pools present in the adipocytes. Briefly, the cells were washed with PBS, fixed with $10 \%$ formalin in PBS for 2 min and washed with distilled water. The cells were then stained with Oil O Red (Sigma O0625) for 1 hour, washed twice with distilled water and examined under a light microscope.

\section{Transfection}

Transient transfection was performed using Lipofectamine 2000 and Opti-MEM-I (Invitrogen) following the manufacturer's protocol. Firstly, the 3T3-L1 cells were cultured in 12-well plates and differentiated into adipocytes as described above. ABCA7 cDNA-lipofectamine complex was then added to the cells in an antibiotic-free media, and after $24 \mathrm{~h}$ the cells were harvested for gene expression analysis.

\section{Statistical analysis}

Data presented are expressed as mean $\pm \mathrm{SE}$ shown by the error bars. Statistical significance was determined using Student's $t$-test with a $p$ value $<0.05$ considered significant.

\section{RESULTS}

\section{Deletion of $A B C A 7$ causes a reduction in white} adipose tissue in female Abca $7^{-/-}$mice

We have previously reported that deletion of ABCA7 causes a significant reduction in WAT mass in female mice [16]. The difference is quite striking with $\sim 40 \%$ less WAT in female Abca7 ${ }^{-/}$mice compared to littermate wild type female mice (Fig. 1A). The size of WAT was not altered in male Abca7 ${ }^{-/-}$ mice. We have also measured the weight of liver and found no significant difference (data not shown). To determine whether the reduction was due to changes in adipocytes, the predominant cells that make up WAT, we prepared and analyzed histological sections of WAT from Abca $7^{-/-}$and wild type mice. We found no significant difference in the morphology (Fig. 1B) or cell size between $\mathrm{Abca} 7^{-/-}$and wild type mice of both sex (Fig. 1C).

\section{Lipin-1 transcription is upregulated in white adipose tissue of female Abca $7^{-/-}$mice}

To understand the changes in WAT caused by ABCA7 deletion, we compared global mRNA expression of WAT from $\mathrm{Abca} 7^{-/}$and wild type mice. Our specific question was does ABCA7 affect WAT development. We discovered that lipin-1 was upregulated by 1.87 fold $(p<0.0001)$ in female $\mathrm{Abca}^{-/-}$mice. This data was subsequently confirmed by qPCR (Fig. 2A). The lipin-1 expression was unaltered in male Abca $7^{-1-}$ mice (Fig. 2A). WAT triglyceride level was also significantly decreased in female $\mathrm{Abca}^{-/-}$mice (Fig. 2B). Lipin-1 encodes the enzyme phosphatidate phosphatase that catalyses the conversion of phosphatidate to diglyceride, which is a key step in triglyceride production in 
A

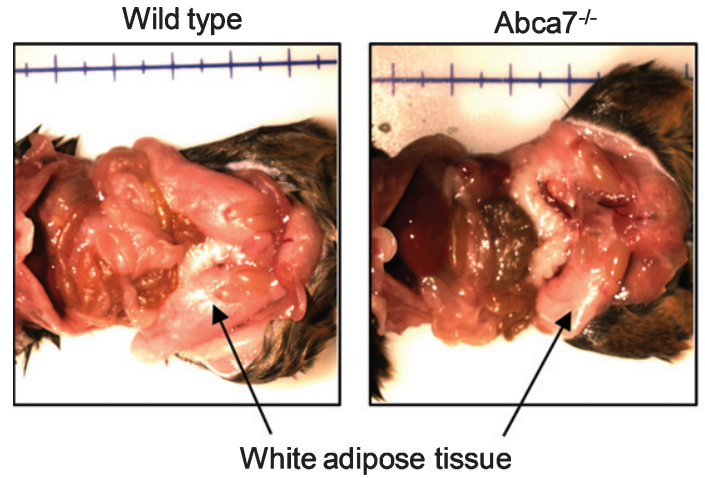

White adipose tissue

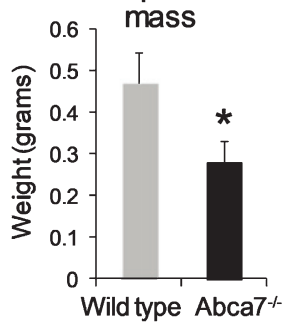

B

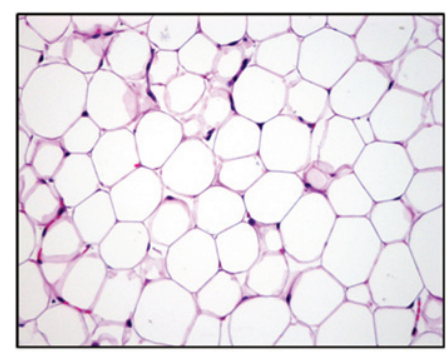

Wild type

C

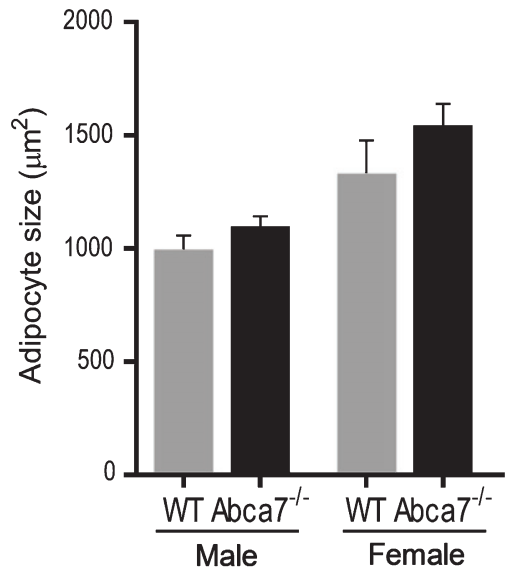

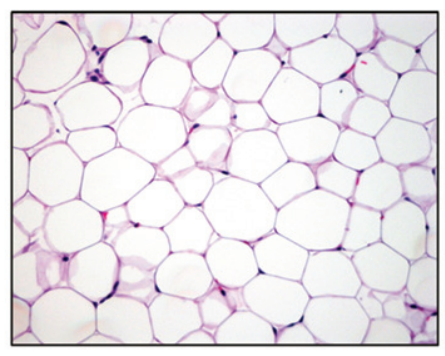

Abca $7^{\text {-1 }}$

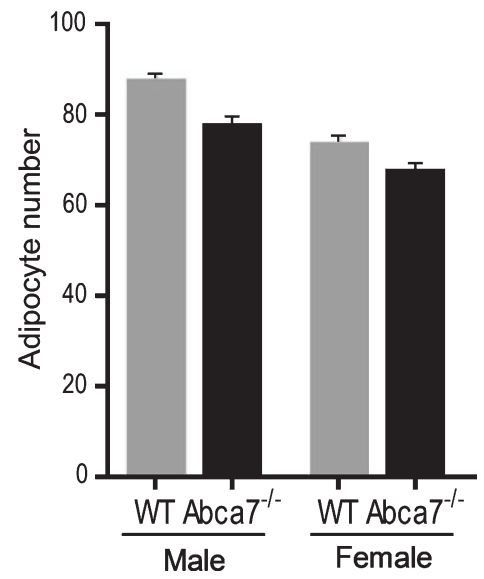

Fig. 1. Deletion of ABCA7 causes a reduction in white adipose tissue (WAT) in female Abca7-/- mice. A) WAT mass is dramatically reduced in female Abca7 ${ }^{-/}$mice. Data represent mean $(n=13)$ and $\mathrm{SE}$ as error bars, ${ }^{*} p<0.05$. B) A representative H\&E stained section of WAT from female wild type and Abca $7^{-/}$mice. C) No significant difference in adipocyte cell size or number between wild type and $\mathrm{Abca}^{-/-}$mice. Data represent mean $(n=6)$ and SE as error bars.

WAT (Fig. 2C). Triglyceride is a major lipid in the lipid pools of adipocytes in WAT [29]. WAT development is dependent on triglyceride production in WAT. Lipin-1 deficiency causes generalized lipodystrophy and impaired WAT development [30]. Upregulation of lipin-1 transcription would indicate lipin-1 enzyme deficiency or dysfunction in female Abca $7^{-/-}$mice. We therefore provide evidence that ABCA7 affects WAT development.
Deletion of $A B C A 7$ reduces the circulating leptin level

Since leptin is primarily produced by WAT and the fact that the circulating leptin level is directly proportional to WAT size [20,21], i.e., the larger the WAT the higher the leptin level (Fig. 3A), we were interested if the circulating leptin level is altered with $\mathrm{ABCA} 7$ deletion. As mentioned above, the circulating leptin 

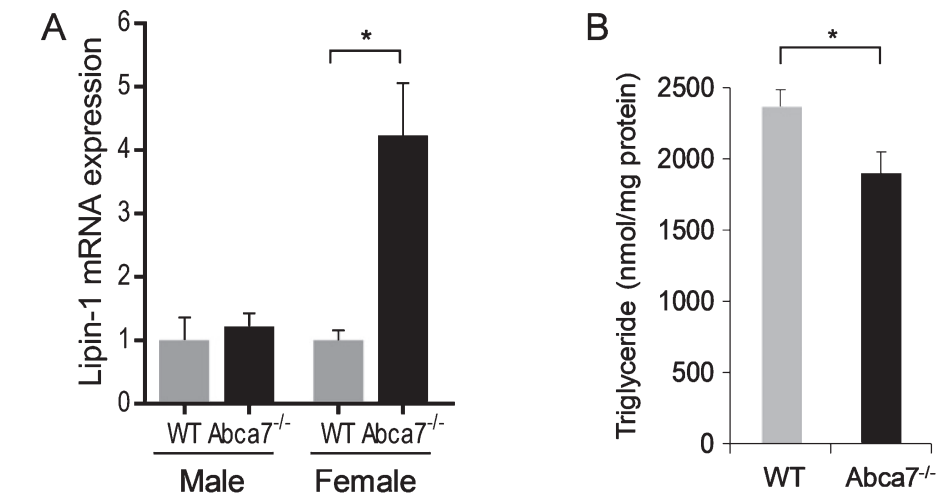

C

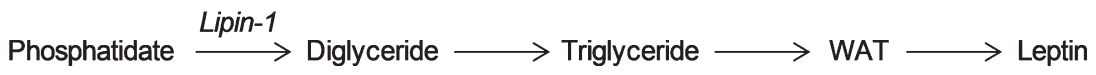

Fig. 2. Lipin-1 expression in white adipose tissue. A) Lipin-1 mRNA expression in WAT of wild type and Abca7 $7^{-/}$mice as measured by qPCR. Data represent mean $(n=10)$ and SE as error bars, ${ }^{*} p<0.05$. B) WAT triglyceride level is significantly decreased in female Abca ${ }^{-/-}$ mice. Data represent mean $(n=6)$ and SE as error bars, ${ }^{*} p<0.05$. C) Lipin-1 converts phosphatidate to diglyceride and triglyceride, which is essential for WAT development and leptin production.

level is important in the $\mathrm{AD}$ context $[23,31]$, i.e., the higher the leptin level the lower the AD risk (Fig. 3B). Here, we measured the circulating leptin level of Abca $7^{-/}$and wild type mice of both sex. Blood was collected (by cardiocentesis) from animals that were fasted overnight and plasma prepared and leptin measured by ELISA. We found that the circulating leptin level was significantly reduced in female Abca $7^{-/-}$ mice compared to female wild type mice (Fig. 3C). The circulating leptin level was not significantly altered in male $\mathrm{Abca}^{-/-}$mice (Fig. 3C).

\section{Leptin expression in white adipose tissue is unaltered with $A B C A 7$ deletion}

We also measured leptin mRNA and protein expression in WAT to determine whether ABCA7 directly affects leptin production. We prepared mRNA and protein from the same quantity of WAT of Abca7 ${ }^{-/-}$and wild type mice of both sex and analyzed leptin expression by qPCR and ELISA. We found no significant difference in either mRNA or protein expression between $\mathrm{Abca} 7^{-/}$and wild type mice of both sex (Fig. 4A). We also conducted an in vitro study to test if ABCA7 had any impact on leptin expression. We differentiated 3T3-L1 preadipocytes into adipocytes; the expression of ABCA7 is upregulated in adipocytes (Fig. 4B). We then transfected adipocytes with ABCA7 cDNA and measured leptin expression. Despite the significant increases in ABCA7 expression (Fig. 4C), we found no significant change in leptin mRNA expression (Fig. 4D).
These data indicate that ABCA7 regulates the circulating leptin level indirectly by altering WAT size rather than altering WAT leptin expression.

\section{Deletion of $A B C A 7$ reduces the circulating insulin level}

Since insulin is recognized as a key hormone that regulates WAT development, i.e., adipogenesis [32-36], we were interested if the circulating insulin level is altered with ABCA7 deletion. Using the same plasma samples prepared from $\mathrm{Abca} 7^{-/-}$and wild type mice above, we measured the circulating insulin levels by ELISA. We found that the circulating insulin levels were significantly reduced in female Abca $7^{-/-}$ mice compared to female wild type mice (Fig. 5). The circulating insulin levels were not significantly altered in male Abca7 ${ }^{-/-}$mice (Fig. 5). These data suggest a plausible explanation that ABCA7 deletion impacts on circulating insulin levels leading to decreased WAT development in female mice.

\section{DISCUSSION}

ABCA7 is a member of ABCA subfamily that predominantly regulates the transport of lipids and other lipophilic molecules across membranes [37, 38]. Genome wide association studies have identified $\mathrm{ABCA} 7$ as a strong susceptibility gene for AD [4-6]. Previous studies have shown that deletion of ABCA7 in a mouse model of $\mathrm{AD}$ exacerbates cerebral $\mathrm{A} \beta$ neuropathology [12], and causes reduced microglial 

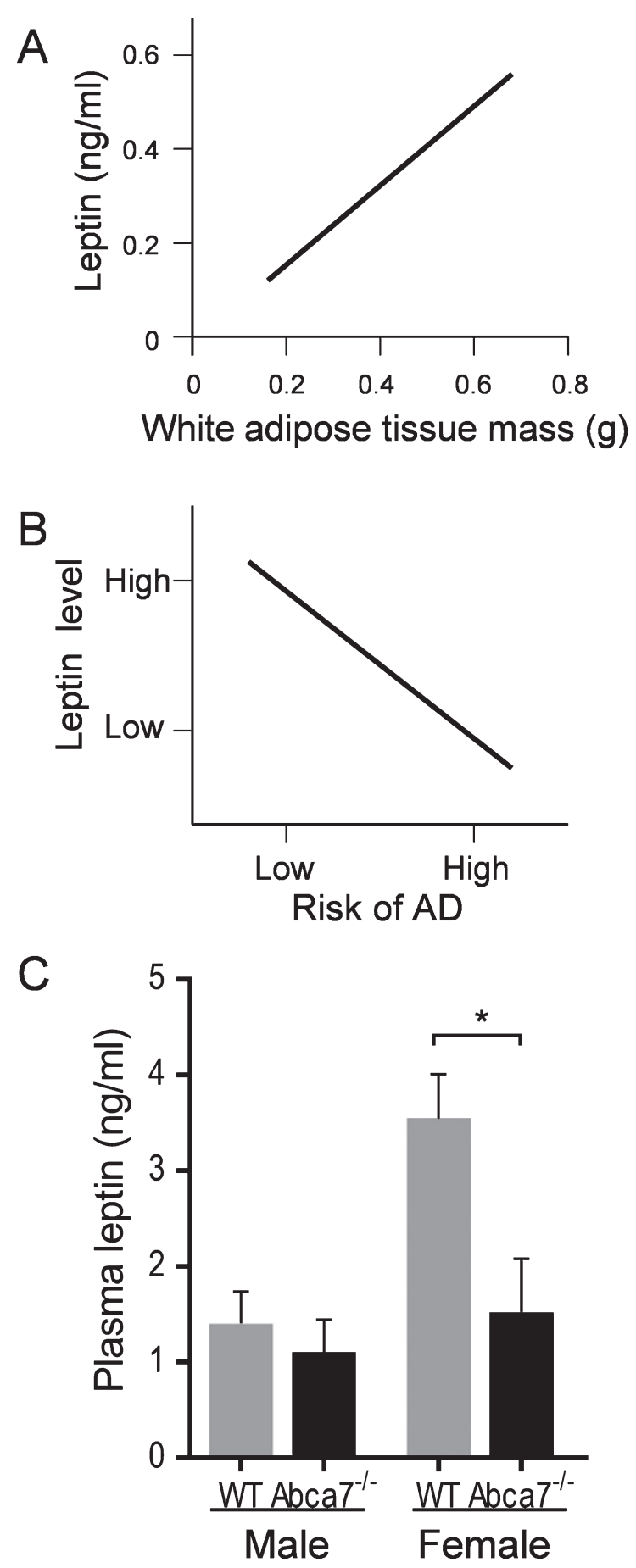

Fig. 3. Deletion of ABCA7 reduces the circulating leptin level in female Abca7 ${ }^{-/-}$mice. A) A theoretical plot depicts the linear relationship between circulating leptin level and WAT mass. B) A theoretical plot depicts the inverse relationship between circulating leptin level and $\mathrm{AD}$ risk, i.e., the higher the leptin level the lower the AD risk. C) Plasma leptin levels were significantly reduced in female Abca7 $7^{-/-}$mice as measured by ELISA. Data represent mean $(n=6)$ and SE as error bars, ${ }^{*} p<0.05$. phagocytic clearance of $A \beta$ peptides [11]. Apart from the effect on $A \beta$ neuropathology, ABCA7 deletion causes a reduction in WAT in female mice [16]. The size of WAT in the AD context is important because the circulating level of leptin produced by WAT is directly proportional to WAT size, and higher circulating leptin levels reduce the risk of developing $\mathrm{AD}$ [23-25]. We have shown that the circulating leptin level is significantly decreased in female Abca ${ }^{-/-}$ mice, consistent with their reduced WAT size. The size of WAT and circulating leptin levels were unaltered in male Abca7 ${ }^{-/-}$mice. We have also shown, using in vivo and in vitro analyses, that ABCA7 does not alter leptin mRNA or protein expression, indicating that the level of leptin produced per unit of WAT mass is unaltered in Abca7 $7^{-/-}$mice. Therefore, ABCA7 regulates the circulating leptin level indirectly by altering WAT size rather than altering WAT leptin production.

Human clinical and epidemiological studies have overwhelmingly demonstrated that leptin is strongly associated with cognition and memory formation and that circulating leptin levels are inversely correlated with AD risk [23-25, 31]. Furthermore, administration of leptin results in significant improvements in cognition in leptin-deficient patients [39] and in transgenic animal models of $\mathrm{AD}$ [17]. In vitro studies show that leptin reduces $A \beta$ secretion [19]. In animal models of $\mathrm{AD}$, leptin reduces soluble $\mathrm{A} \beta$ levels and $A \beta$ plaque load in the hippocampus [17]. Further evidence of the involvement of leptin in $\mathrm{AD}$ pathogenesis comes from the fact that leptin receptors are highly expressed in the hippocampus [40,41], a region of the brain intrinsically involved in memory and cognition. In hippocampal CA1 neurons, leptin facilitates presynaptic transmitter release and postsynaptic sensitivity, resulting in improved spatial learning and memory [42]. These data strongly suggest that leptin has the potential to modulate AD pathogenesis and reinforces the emerging consensus that leptin homeostasis could be a possible therapeutic target for $\mathrm{AD}$ treatment.

We have shown that lipin-1 transcription in WAT is significantly upregulated in female Abca $7^{-/-}$mice, providing evidence that ABCA7 affects WAT development. Lipin-1 is essential for the production of triglyceride required for WAT development [30]; triglyceride is a major lipid in the lipid pools of adipocytes in WAT [29]. Uncontrolled overexpression of lipin-1 protein would lead to obesity [43]. Upregulation of lipin-1 transcription would indicate that that lipin-1 is deficient or dysfunctional, result- 

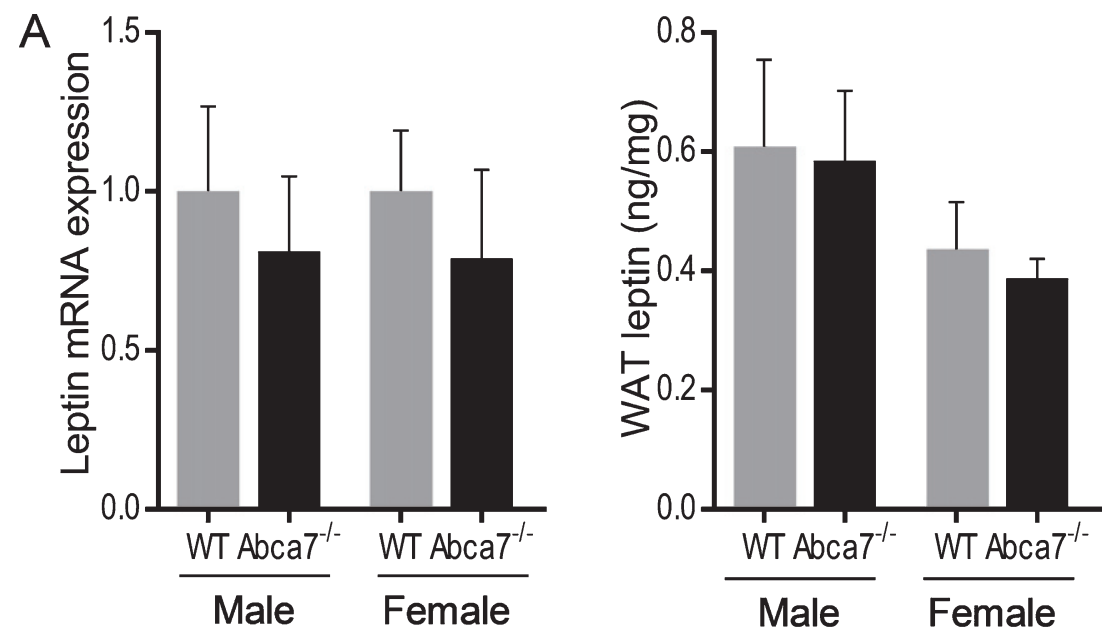

B
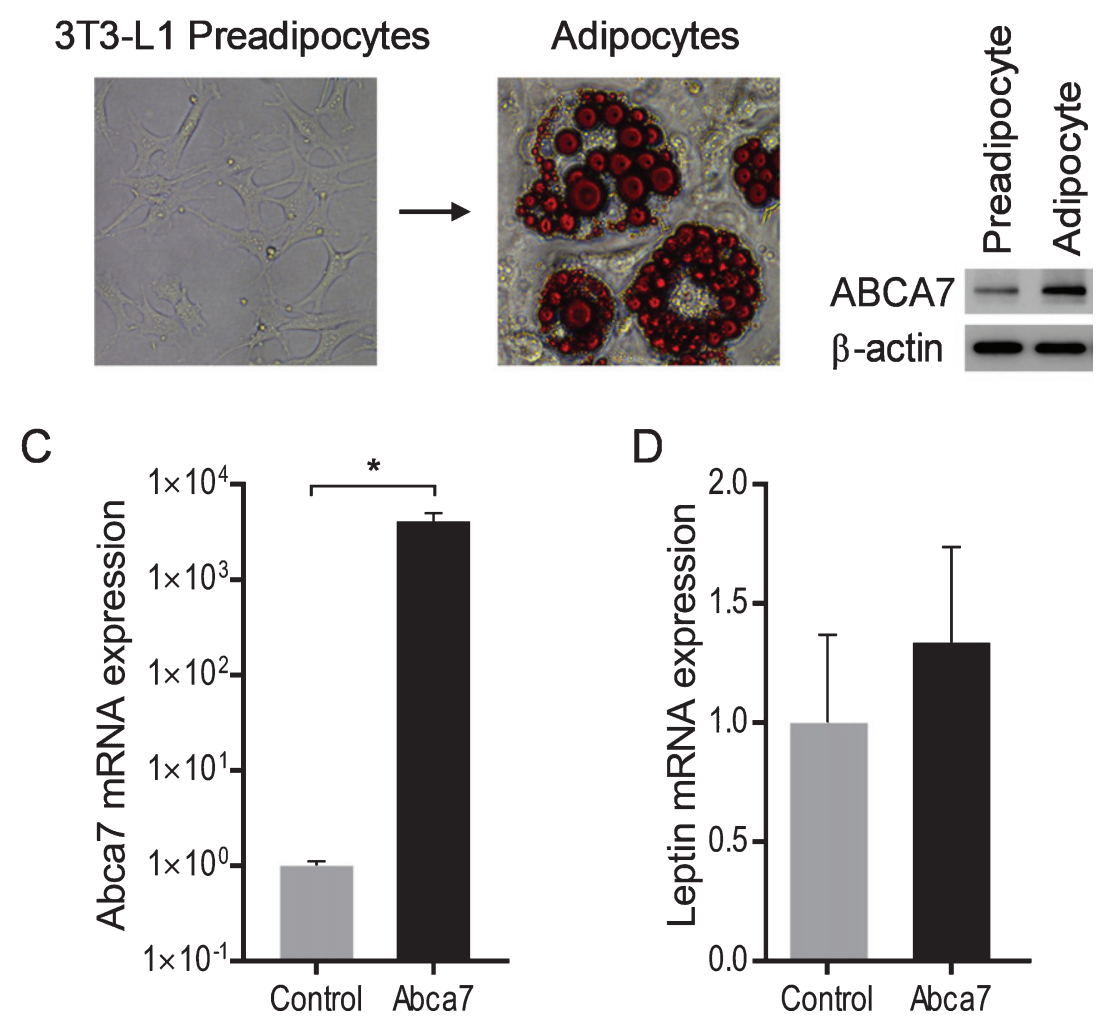

Fig. 4. Leptin expression in white adipose tissue and adipocytes. A) No significant difference in leptin mRNA or protein expression in WAT between wild type and Abca7 ${ }^{-1}$ mice as measured by qPCR and ELISA respectively. Data represent mean $(n=6)$ and SE as error bars. B) 3T3-L1 preadipocytes were differentiated into adipocytes. Fully differentiated adipocytes contain lipid pools as stained by Oil O Red. The expression of ABCA7 is upregulated in adipocytes. C) Adipocytes were successfully transfected with Abca7 cDNA as measured by qPCR; an empty vector was used as a control. Data represent mean $(n=6)$ and SE as error bars, ${ }^{*} p<0.01$. D) No significant change in leptin mRNA expression in the Abca7-transfected adipocytes as measured by qPCR.

ing in impaired WAT development, which is the case for female $\mathrm{Abca} 7^{-/}$mice. It is interesting to note that lipin-1 has a secondary function in that it reg- ulates extracellular signal-regulated kinase (ERK) in skeletal muscle differentiation [44]. Previously, it has been shown that ERK phosphorylation process was 


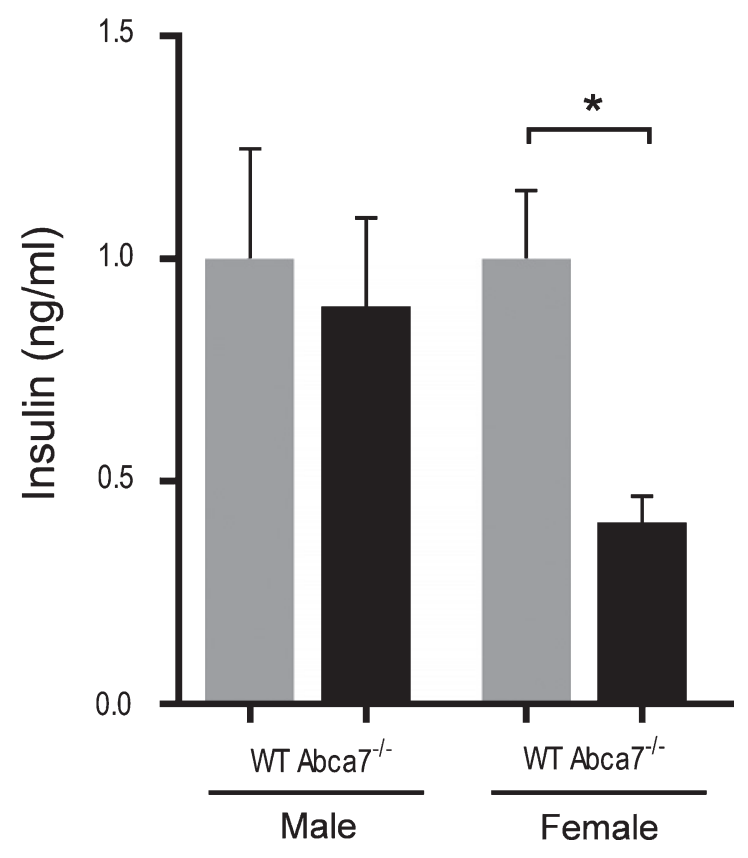

Fig. 5. Deletion of $\mathrm{ABCA} 7$ reduces the circulating insulin level. Plasma insulin levels were significantly reduced in female $\mathrm{Abca}^{-1-}$ mice as measured by ELISA. Data represent mean $(n=6)$ and SE as error bars, ${ }^{*} p<0.05$.

defective in ABCA7-deficient cells [45]. It is also possible that other factors may have influenced the expression of lipin-1, such as stress; stress would cause increases in glucocorticoid levels, which in turn upregulates lipin-1 expression [46]. A detailed analysis of lipid content of WAT in Abca $7^{-/-}$mice would help to further understand the role of ABCA7 in adipogenesis and WAT development.

We showed that the circulating insulin level was severely affected by ABCA7 deletion. Insulin is a master regulator of adipogenesis, the process of differentiating preadipocytes into mature adipocytes [32]. Therefore, ABCA7 appears to affect WAT development, i.e., adipogenesis, via altering the circulating insulin level. The development of fully differentiated adipocytes from preadipocytes requires a cascade of transcriptional factors, which are activated by insulin. The transcription factors are critical for attaining the mature morphological and biochemical phenotype of adipocytes [33, 34]. Insulin is also known to activate lipogenic and glycolytic enzymes that are required for lipogenesis in WAT development [36], and therefore other roles of insulin in WAT development could also be affected by ABCA7 deletion.
At this stage it is unclear why there is a gender difference in the effect of ABCA7 deletion on insulin levels and WAT development. WAT development is a complex process that requires a number of hormones including sex steroids [47]. Whether ABCA7 affects the level of sex steroids is yet to be determined. What is interesting is that sex steroids (i.e., estrogens and testosterone) are synthesized from the precursor molecule cholesterol. Since ABCA7 is a regulator of cholesterol metabolism, it is plausible to think that ABCA7 deletion could affect sex steroid production. Changes in cholesterol level in the gonads impact on sex steroid production [48]. In the case of ABCA1, a member of the ABCA subfamily and a homolog of $\mathrm{ABCA} 7$ [3], the location of insulin regulation appears to be at the pancreas [49-51]. ABCA1 deletion or loss-of-function mutations cause accumulation of cholesterol in cells resulting in decreases in high density lipoprotein (HDL)-cholesterol [52]. ABCA1 deletion in mice causes accumulation of cholesterol in the $\beta$ cells of the pancreas causing impaired insulin secretion $[49,50]$. Likewise in humans, loss-of-function mutations in ABCA1 cause reduction in the insulin secretory capacity of the $\beta$ cells of the pancreas [51]. It is interesting to note that ABCA7 deletion also causes decreases in HDLcholesterol but only in female Abca $7^{-/-}$mice [16]. Whether the insulin secretory capacity of the pancreas is impaired in female Abca $7^{-/-}$mice is yet to be determined.

There is a considerable amount of data which indicate that $\mathrm{ABCA} 7$ contributes to $\mathrm{AD}$ pathology $[12,14,53-59]$, particularly affecting $\mathrm{A} \beta \mathrm{PP}$ processing $[14,53]$ and the phagocytic clearance of $A \beta$ peptides [45, 60-62]. Our current study is the first report indicating that ABCA7 alters WAT development. This study has revealed a pathway by which ABCA7 regulates WAT development and leptin levels. It has identified new targets for controlling leptin levels that may impact AD pathology. Leptin has not been used in clinical trial to treat $\mathrm{AD}$ and therefore this work provides an invaluable preclinical proof-ofconcept that leptin is a potential therapy for $\mathrm{AD}$ and for those at risk presenting with low leptin levels.

\section{ACKNOWLEDGMENTS}

This work was supported by grants from the Mason Foundation (to W.S.K.) and the University of New South Wales Goldstar Award (to W.S.K.). G.M.H. is a National Health and Medical Research Coun- 
cil (NHMRC) Senior Principal Research Fellow and S.B. is a NHMRC Research Fellow. The authors wish to thank Prof M. Freeman (Massachusetts General Hospital, Boston) for $\mathrm{Abca} 7^{-/-}$mice.

\section{CONFLICT OF INTEREST}

The authors declare that they have no conflict of interest.

\section{REFERENCES}

[1] Dean M, Hamon Y, Chimini G (2001) The human ATPbinding cassette $(\mathrm{ABC})$ transporter superfamily. J Lipid Res 42, 1007-1017.

[2] Abe-Dohmae S, Ikeda Y, Matsuo M, Hayashi M, Okuhira K, Ueda K, Yokoyama S (2004) Human ABCA7 supports apolipoprotein-mediated release of cellular cholesterol and phospholipid to generate high density lipoprotein. $J$ Biol Chem 279, 604-611.

[3] Kaminski WE, Orso E, Diederich W, Klucken J, Drobnik W, Schmitz G (2000) Identification of a novel human sterol-sensitive ATP-binding cassette transporter (ABCA7). Biochem Biophys Res Commun 273, 532-538.

[4] Hollingworth P, Harold D, Sims R, Gerrish A, Lambert JC, Carrasquillo MM, Abraham R, Hamshere ML, Pahwa JS, Moskvina V, Dowzell K, Jones N, Stretton A, Thomas C, Richards A, Ivanov D, Widdowson C, Chapman J, Lovestone S, Powell J, Proitsi P, Lupton MK, Brayne C, Rubinsztein DC, Gill M, Lawlor B, Lynch A, Brown KS, Passmore PA, Craig D, McGuinness B, Todd S, Holmes C, Mann D, Smith AD, Beaumont H, Warden D, Wilcock G, Love S, Kehoe PG, Hooper NM, Vardy ER, Hardy J, Mead S, Fox NC, Rossor M, Collinge J, Maier W, Jessen F, Ruther E, Schurmann B, Heun R, Kolsch H, van den Bussche H, Heuser I, Kornhuber J, Wiltfang J, Dichgans M, Frolich L, Hampel H, Gallacher J, Hull M, Rujescu D, Giegling I, Goate AM, Kauwe JS, Cruchaga C, Nowotny P, Morris JC, Mayo K, Sleegers K, Bettens K, Engelborghs S, De Deyn PP, Van Broeckhoven C, Livingston G, Bass NJ, Gurling H, McQuillin A, Gwilliam R, Deloukas P, AlChalabi A, Shaw CE, Tsolaki M, Singleton AB, Guerreiro R, Muhleisen TW, Nothen MM, Moebus S, Jockel KH, Klopp N, Wichmann HE, Pankratz VS, Sando SB, Aasly JO, Barcikowska M, Wszolek ZK, Dickson DW, GraffRadford NR, Petersen RC, van Duijn CM, Breteler MM, Ikram MA, DeStefano AL, Fitzpatrick AL, Lopez O, Launer LJ, Seshadri S, Berr C, Campion D, Epelbaum J, Dartigues JF, Tzourio C, Alperovitch A, Lathrop M, Feulner TM, Friedrich P, Riehle C, Krawczak M, Schreiber S, Mayhaus M, Nicolhaus S, Wagenpfeil S, Steinberg S, Stefansson H, Stefansson K, Snaedal J, Bjornsson S, Jonsson PV, Chouraki V, Genier-Boley B, Hiltunen M, Soininen H, Combarros O, Zelenika D, Delepine M, Bullido MJ, Pasquier F, Mateo I, Frank-Garcia A, Porcellini E, Hanon O, Coto E, Alvarez V, Bosco P, Siciliano G, Mancuso M, Panza F, Solfrizzi V, Nacmias B, Sorbi S, Bossu P, Piccardi P, Arosio B, Annoni G, Seripa D, Pilotto A, Scarpini E, Galimberti D, Brice A, Hannequin D, Licastro F, Jones L, Holmans PA, Jonsson T, Riemenschneider M, Morgan K, Younkin SG, Owen MJ, O'Donovan M, Amouyel P, Williams J (2011) Common variants at ABCA7, MS4A6A/MS4A4E, EPHA1, CD33 and CD2AP are associated with Alzheimer's disease. Nat Genet 43, 429-435.

[5] Steinberg S, Stefansson H, Jonsson T, Johannsdottir H, Ingason A, Helgason H, Sulem P, Magnusson OT, Gudjonsson SA, Unnsteinsdottir U, Kong A, Helisalmi S, Soininen H, Lah JJ, Aarsland D, Fladby T, Ulstein ID, Djurovic S, Sando SB, White LR, Knudsen GP, Westlye LT, Selbaek G, Giegling I, Hampel H, Hiltunen M, Levey AI, Andreassen OA, Rujescu D, Jonsson PV, Bjornsson S, Snaedal J, Stefansson K (2015) Loss-of-function variants in ABCA7 confer risk of Alzheimer's disease. Nat Genet 47, 445-447.

[6] Cuyvers E, De Roeck A, Van den Bossche T, Van Cauwenberghe C, Bettens K, Vermeulen S, Mattheijssens M, Peeters K, Engelborghs S, Vandenbulcke M, Vandenberghe R, De Deyn PP, Van Broeckhoven C, Sleegers K (2015) Mutations in ABCA7 in a Belgian cohort of Alzheimer's disease patients: a targeted resequencing study. Lancet Neurol 14, 814-822.

[7] Lambert JC, Ibrahim-Verbaas CA, Harold D, Naj AC, Sims R, Bellenguez C, DeStafano AL, Bis JC, Beecham GW, Grenier-Boley B, Russo G, Thorton-Wells TA, Jones N, Smith AV, Chouraki V, Thomas C, Ikram MA, Zelenika D, Vardarajan BN, Kamatani Y, Lin CF, Gerrish A, Schmidt H, Kunkle B, Dunstan ML, Ruiz A, Bihoreau MT, Choi SH, Reitz C, Pasquier F, Cruchaga C, Craig D, Amin N, Berr C, Lopez OL, De Jager PL, Deramecourt V, Johnston JA, Evans D, Lovestone S, Letenneur L, Morón FJ, Rubinsztein DC, Eiriksdottir G, Sleegers K, Goate AM, Fiévet N, Huentelman MW, Gill M, Brown K, Kamboh MI, Keller L, Barberger-Gateau P, McGuiness B, Larson EB, Green R, Myers AJ, Dufouil C, Todd S, Wallon D, Love S, Rogaeva E, Gallacher J, St George-Hyslop P, Clarimon J, Lleo A, Bayer A, Tsuang DW, Yu L, Tsolaki M, Bossú P, Spalletta G, Proitsi P, Collinge J, Sorbi S, Sanchez-Garcia F, Fox NC, Hardy J, Deniz Naranjo MC, Bosco P, Clarke R, Brayne C, Galimberti D, Mancuso M, Matthews F; European Alzheimer's Disease Initiative (EADI), Genetic and Environmental Risk in Alzheimer's Disease; Alzheimer's Disease Genetic Consortium; Cohorts for Heart and Aging Research in Genomic Epidemiology, Moebus S, Mecocci P, Del Zompo M, Maier W, Hampel H, Pilotto A, Bullido M, Panza F, Caffarra P, Nacmias B, Gilbert JR, Mayhaus M, Lannefelt L, Hakonarson H, Pichler S, Carrasquillo MM, Ingelsson M, Beekly D, Alvarez V, Zou F, Valladares O, Younkin SG, Coto E, Hamilton-Nelson KL, Gu W, Razquin C, Pastor P, Mateo I, Owen MJ, Faber KM, Jonsson PV, Combarros O, O'Donovan MC, Cantwell LB, Soininen H, Blacker D, Mead S, Mosley TH Jr, Bennett DA, Harris TB, Fratiglioni L, Holmes C, de Bruijn RF, Passmore P, Montine TJ, Bettens K, Rotter JI, Brice A, Morgan K, Foroud TM, Kukull WA, Hannequin D, Powell JF, Nalls MA, Ritchie K, Lunetta KL, Kauwe JS, Boerwinkle E, Riemenschneider M, Boada M, Hiltuenen M, Martin ER, Schmidt R, Rujescu D, Wang LS, Dartigues JF, Mayeux R, Tzourio C, Hofman A, Nöthen MM, Graff C, Psaty BM, Jones L, Haines JL, Holmans PA, Lathrop M, Pericak-Vance MA, Launer LJ, Farrer LA, van Duijn CM, Van Broeckhoven C, Moskvina V, Seshadri S, Williams J, Schellenberg GD, Amouyel P (2013) Meta-analysis of 74,046 individuals identifies 11 new susceptibility loci for Alzheimer's disease. Nat Genet 45, 1452-1458.

[8] Morgan K (2011) The three new pathways leading to Alzheimer's disease. Neuropathol Appl Neurobiol 37, 353357. 
[9] Jehle AW, Gardai SJ, Li S, Linsel-Nitschke P, Morimoto K, Janssen WJ, Vandivier RW, Wang N, Greenberg S, Dale BM, Qin C, Henson PM, Tall AR (2006) ATP-binding cassette transporter A7 enhances phagocytosis of apoptotic cells and associated ERK signaling in macrophages. J Cell Biol 174, 547-556.

[10] Iwamoto N, Abe-Dohmae S, Sato R, Yokoyama S (2006) ABCA7 expression is regulated by cellular cholesterol through the SREBP2 pathway and associated with phagocytosis. J Lipid Res 47, 1915-1927.

[11] Fu Y, Hsiao JH, Paxinos G, Halliday GM, Kim WS (2016) ABCA7 mediates phagocytic clearance of amyloid-beta in the brain. J Alzheimers Dis 54, 569-584.

[12] Kim WS, Li H, Ruberu K, Chan S, Elliott DA, Low JK, Cheng D, Karl T, Garner B (2013) Deletion of Abca7 increases cerebral amyloid-beta accumulation in the J20 mouse model of Alzheimer's disease. J Neurosci 33, 43874394.

[13] Sakae N, Liu CC, Shinohara M, Frisch-Daiello J, Ma L, Yamazaki Y, Tachibana M, Younkin L, Kurti A, Carrasquillo MM, Zou F, Sevlever D, Bisceglio G, Gan M, Fol R, Knight P, Wang M, Han X, Fryer JD, Fitzgerald ML, Ohyagi Y, Younkin SG, Bu G, Kanekiyo T (2016) ABCA7 deficiency accelerates amyloid-beta generation and Alzheimer's neuronal pathology. J Neurosci 36, 3848-3859.

[14] Satoh K, Abe-Dohmae S, Yokoyama S, St George-Hyslop P, Fraser PE (2015) ATP-binding cassette transporter A7 (ABCA7) loss of function alters Alzheimer amyloid processing. J Biol Chem 290, 24152-24165.

[15] Chan SL, Kim WS, Kwok JB, Hill AF, Cappai R, Rye KA, Garner B (2008) ATP-binding cassette transporter A7 regulates processing of amyloid precursor protein in vitro. J Neurochem 106, 793-804.

[16] Kim WS, Fitzgerald ML, Kang K, Okuhira K, Bell SA, Manning JJ, Koehn SL, Lu N, Moore KJ, Freeman MW (2005) Abca7 null mice retain normal macrophage phosphatidylcholine and cholesterol efflux activity despite alterations in adipose mass and serum cholesterol levels. J Biol Chem $\mathbf{2 8 0}$, 3989-3995.

[17] Greco SJ, Bryan KJ, Sarkar S, Zhu X, Smith MA, Ashford JW, Johnston JM, Tezapsidis N, Casadesus G (2010) Leptin reduces pathology and improves memory in a transgenic mouse model of Alzheimer's disease. J Alzheimers Dis 19, 1155-1167.

[18] Beccano-Kelly D, Harvey J (2012) Leptin: A novel therapeutic target in Alzheimer's disease? Int J Alzheimers Dis 2012, 594137.

[19] Fewlass DC, Noboa K, Pi-Sunyer FX, Johnston JM, Yan SD, Tezapsidis N (2004) Obesity-related leptin regulates Alzheimer's Abeta. FASEB J 18, 1870-1878.

[20] Chan JL, Wong SL, Mantzoros CS (2008) Pharmacokinetics of subcutaneous recombinant methionyl human leptin administration in healthy subjects in the fed and fasting states: Regulation by gender and adiposity. Clin Pharmacokinet 47, 753-764.

[21] Considine RV, Sinha MK, Heiman ML, Kriauciunas A, Stephens TW, Nyce MR, Ohannesian JP, Marco CC, McKee LJ, Bauer TL, Caro JF (1996) Serum immunoreactive-leptin concentrations in normal-weight and obese humans. N Engl J Med 334, 292-295.

[22] Zhang Y, Proenca R, Maffei M, Barone M, Leopold L, Friedman JM (1994) Positional cloning of the mouse obese gene and its human homologue. Nature 372, 425-432.
[23] Power DA, Noel J, Collins R, O'Neill D (2001) Circulating leptin levels and weight loss in Alzheimer's disease patients. Dement Geriatr Cogn Disord 12, 167-170.

[24] Holden KF, Lindquist K, Tylavsky FA, Rosano C, Harris TB, Yaffe K (2009) Serum leptin level and cognition in the elderly: Findings from the Health ABC Study. Neurobiol Aging 30, 1483-1489.

[25] Lieb W, Beiser AS, Vasan RS, Tan ZS, Au R, Harris TB, Roubenoff R, Auerbach S, DeCarli C, Wolf PA, Seshadri S (2009) Association of plasma leptin levels with incident Alzheimer disease and MRI measures of brain aging. JAMA 302, 2565-2572.

[26] Parlee SD, Lentz SI, Mori H, MacDougald OA (2014) Quantifying size and number of adipocytes in adipose tissue. Methods Enzymol 537, 93-122.

[27] Galarraga M, Campion J, Munoz-Barrutia A, Boque N, Moreno H, Martinez JA, Milagro F, Ortiz-de-Solorzano C (2012) Adiposoft: Automated software for the analysis of white adipose tissue cellularity in histological sections. J Lipid Res 53, 2791-2796.

[28] Poulos SP, Dodson MV, Hausman GJ (2010) Cell line models for differentiation: Preadipocytes and adipocytes. Exp Biol Med 235, 1185-1193.

[29] Albright AL, Stern JS (1998) Adipose tissue. In Encyclopedia of Sports Medicine and Science, Fahey TD, ed. Internet Society for Sport Science, http://sportsci.org

[30] Reue K, Xu P, Wang XP, Slavin BG (2000) Adipose tissue deficiency, glucose intolerance, and increased atherosclerosis result from mutation in the mouse fatty liver dystrophy (fld) gene. J Lipid Res 41, 1067-1076.

[31] Bigalke B, Schreitmuller B, Sopova K, Paul A, Stransky E, Gawaz M, Stellos K, Laske C (2011) Adipocytokines and CD34 progenitor cells in Alzheimer's disease. PLoS One 6 , e20286.

[32] Klemm DJ, Leitner JW, Watson P, Nesterova A, Reusch JE-B, Goalstone ML, Draznin B (2001) Insulin-induced adipocyte differentiation: Activation of CREB rescues adipogenesis from the arrest caused by inhibition of prenylation. J Biol Chem 276, 28430-28435.

[33] Rosen ED, Spiegelman BM (2000) Molecular regulation of adipogenesis. Annu Rev Cell Dev Biol 16, 145-171.

[34] Rosen ED, Hsu CH, Wang X, Sakai S, Freeman MW, Gonzalez FJ, Spiegelman BM (2002) C/EBPalpha induces adipogenesis through PPARgamma: A unified pathway. Genes Dev 16, 22-26.

[35] Zhao AZ, Bornfeldt KE, Beavo JA (1998) Leptin inhibits insulin secretion by activation of phosphodiesterase 3B. J Clin Invest 102, 869-873.

[36] Kersten S (2001) Mechanisms of nutritional and hormonal regulation of lipogenesis. EMBO Rep 2, 282-286.

[37] Kim WS, Weickert CS, Garner B (2008) Role of ATPbinding cassette transporters in brain lipid transport and neurological disease. J Neurochem 104, 1145-1166.

[38] Quazi F, Molday RS (2013) Differential phospholipid substrates and directional transport by ATP-binding cassette proteins $\mathrm{ABCA} 1, \mathrm{ABCA} 7$, and $\mathrm{ABCA} 4$ and diseasecausing mutants. J Biol Chem 288, 34414-34426.

[39] Paz-Filho GJ, Babikian T, Asarnow R, Delibasi T, Esposito K, Erol HK, Wong ML, Licinio J (2008) Leptin replacement improves cognitive development. PLoS One 3, e3098.

[40] Harvey J (2007) Leptin: A diverse regulator of neuronal function. J Neurochem 100, 307-313.

[41] Caron E, Sachot C, Prevot V, Bouret SG (2010) Distribution of leptin-sensitive cells in the postnatal and adult mouse brain. J Comp Neurol 518, 459-476. 
[42] Oomura Y, Aou S, Fukunaga K (2010) Prandial increase of leptin in the brain activates spatial learning and memory. Pathophysiology 17, 119-127.

[43] Reue K, Dwyer JR (2009) Lipin proteins and metabolic homeostasis. J Lipid Res 50(Suppl), S109-S114.

[44] Jiang W, Zhu J, Zhuang X, Zhang X, Luo T, Esser KA, Ren $H$ (2015) Lipin1 regulates skeletal muscle differentiation through extracellular signal-regulated kinase (ERK) activation and cyclin D complex-regulated cell cycle withdrawal. J Biol Chem 290, 23646-23655.

[45] Jehle AW, Gardai SJ, Li S, Linsel-Nitschke P, Morimoto K, Janssen WJ, Vandivier RW, Wang N, Greenberg S, Dale BM, Qin C, Henson PM, Tall AR (2006) ATP-binding cassette transporter A7 enhances phagocytosis of apoptotic cells and associated ERK signaling in macrophages. J Cell Biol 174, 547-556.

[46] Munck A, Guyre PM, Holbrook NJ (1984) Physiological functions of glucocorticoids in stress and their relation to pharmacological actions. Endocr Rev 5, 25-44.

[47] Law J, Bloor I, Budge H, Symonds ME (2014) The influence of sex steroids on adipose tissue growth and function. Horm Mol Biol Clin Investig 19, 13-24.

[48] Miller WL (1988) Molecular biology of steroid hormone synthesis. Endocr Rev 9, 295-318.

[49] Brunham LR, Kruit JK, Pape TD, Timmins JM, Reuwer AQ, Vasanji Z, Marsh BJ, Rodrigues B, Johnson JD, Parks JS, Verchere CB, Hayden MR (2007) Beta-cell ABCA1 influences insulin secretion, glucose homeostasis and response to thiazolidinedione treatment. Nat Med 13, 340-347.

[50] Kruit JK, Wijesekara N, Fox JE, Dai XQ, Brunham LR, Searle GJ, Morgan GP, Costin AJ, Tang R, Bhattacharjee A, Johnson JD, Light PE, Marsh BJ, Macdonald PE, Verchere CB, Hayden MR (2011) Islet cholesterol accumulation due to loss of ABCA1 leads to impaired exocytosis of insulin granules. Diabetes 60, 3186-3196.

[51] Vergeer M, Brunham LR, Koetsveld J, Kruit JK, Verchere CB, Kastelein JJ, Hayden MR, Stroes ES (2010) Carriers of loss-of-function mutations in ABCA1 display pancreatic beta-cell dysfunction. Diabetes Care 33, 869-874.

[52] Young SG, Fielding CJ (1999) The ABCs of cholesterol efflux. Nat Genet 22, 316-318.

[53] Chan SL, Kim WS, Kwok JB, Hill AF, Cappai R, Rye KA, Garner B (2008) ATP-binding cassette transporter A7 regulates processing of amyloid precursor protein in vitro. J Neurochem 106, 793-804.
[54] Chung SJ, Kim MJ, Kim YJ, Kim J, You S, Jang EH, Kim SY, Lee JH (2014) CR1, ABCA7, and APOE genes affect the features of cognitive impairment in Alzheimer's disease. J Neurol Sci 339, 91-96.

[55] Liu G, Li F, Zhang S, Jiang Y, Ma G, Shang H, Liu J, Feng R, Zhang L, Liao M, Zhao B, Li K (2014) Analyzing large-scale samples confirms the association between the ABCA7 rs3764650 polymorphism and Alzheimer's disease susceptibility. Mol Neurobiol 50, 757-764.

[56] Magnusson OT, Gudjonsson SA, Unnsteinsdottir U, Kong A, Helisalmi S, Soininen H, Lah JJ, Aarsland D, Fladby T, Ulstein ID, Djurovic S, Sando SB, White LR, Knudsen GP, Westlye LT, Selbaek G, Giegling I, Hampel H, Hiltunen M, Levey AI, Andreassen OA, Rujescu D, Jonsson PV, Bjornsson S, Snaedal J, Stefansson K, Liao YC, Lee WJ, Hwang JP, Wang YF, Tsai CF, Wang PN, Wang SJ, Fuh JL (2014) ABCA7 gene and the risk of Alzheimer's disease in Han Chinese in Taiwan. Nat Genet 35, 2423.e2427-2423.e2413.

[57] Rosenthal SL, Kamboh MI (2014) Late-onset Alzheimer's disease genes and the potentially implicated pathways. Curr Genet Med Rep 2, 85-101.

[58] Steinberg S, Stefansson H, Jonsson T, Johannsdottir H, Ingason A, Helgason H, Sulem P, Magnusson OT, Gudjonsson SA, Unnsteinsdottir U, Kong A, Helisalmi S, Soininen H, Lah JJ; DemGene, Aarsland D, Fladby T, Ulstein ID, Djurovic S, Sando SB, White LR, Knudsen GP, Westlye LT, Selbæk G, Giegling I, Hampel H, Hiltunen M, Levey A, Andreassen OA, Rujescu D, Jonsson PV, Bjornsson S, Snaedal J, Stefansson K (2015) Loss-of-function variants in ABCA7 confer risk of Alzheimer's disease. Nat Genet 47, 445-447.

[59] Vasquez JB, Fardo DW, Estus S (2013) ABCA7 expression is associated with Alzheimer's disease polymorphism and disease status. Neurosci Lett 556, 58-62.

[60] Iwamoto N, Abe-Dohmae S, Sato R, Yokoyama S (2006) ABCA7 expression is regulated by cellular cholesterol through the SREBP2 pathway and associated with phagocytosis. J Lipid Res 47, 1915-1927.

[61] Li H, Karl T, Garner B (2015) Understanding the function of ABCA7 in Alzheimer's disease. Biochem Soc Trans 43, 920-923.

[62] Tanaka N, Abe-Dohmae S, Iwamoto N, Fitzgerald ML, Yokoyama S (2011) HMG-CoA reductase inhibitors enhance phagocytosis by upregulating ATP-binding cassette transporter A7. Atherosclerosis 217, 407-414. 